\title{
The Effect of Experience, Independence, and Gender on Auditor Professional Scepticism with Professional Ethics as Moderating
}

\author{
Tuti Dewi Ratna*1, Indah Anisykurlillah ${ }^{2}$ \\ ${ }^{1,2}$ Accounting Department, Faculty of Economics, Universitas Negeri Semarang, Indonesia
}

\begin{tabular}{l} 
ARTICLE INFO \\
\hline Article History: \\
Received September $12^{\text {th }}, 2019$ \\
Accepted June $30^{\text {th }}, 2020$ \\
Available July $30^{\text {th }}, 2020$
\end{tabular}

\section{Keywords:}

Ethic; Experience; Gender; Independence; Professional Scepticism

\begin{abstract}
This study is aimed to analyze some factors that affect the scepticism of professional auditor. These factors are experience, independence, gender, and professional ethics. Population of this research were 347 auditors who work at the public accounting firm in Central Java and Yogyakarta. Sampling technique used convenience sampling and obtained sample of 83 auditors. For collecting data, the writer used questionnaires. The method of analyzing data was descriptive analysis and multiple regression analysis with IBM SPSS version 21 application. The statistical method used to examine the hypothesis was Moderated Regression Analysis (MRA). The results of this study indicate that the experience of auditors, gender, and professional ethics have a significant effect on auditor professional scepticism. While independence, interaction of experience and professional ethics, interaction of independence and professional ethics, as well as the interaction of gender and professional ethics have no significant effect on professional scepticism of auditors. The conclusion of this study is the need for experience, independence, and high ethical awareness for male and female auditors to remain sceptical in every audit practice.
\end{abstract}

(C) 2020 Published by UNNES. This is an open access article under the CC BY license (http://creativecommons.org/licenses/by/4.0/)

\section{INTRODUCTION}

Financial information in the form of financial statements presented by a company does not necessarily describe all the economic activities of the company and has been recorded as it should, financial statements may not be presented honestly in accordance with the actual situation in the company. Reliable financial information must meet accounting principles, in accordance with existing standards and regulations. The more complex the society, the greater the possibility of unreliable information received by decision makers. The reasons include information distance, bias and motives from information providers, the amount of data, and the existence of very complex exchange information (Arens et.al, 2015). Thus, independent services is needed, independent services provided by independent auditors who carry out audits, the auditor will focus on whether during the accounting period the information presented and recorded by the client have accurately described the event or economic event that occurs (Arens et al., 2015). In this case, the auditor's professional scepticism is needed to detect the presence or absence of intentional or

\footnotetext{
*E-mail: tutidewiratna@gmail.com

_Address: 2nd Floor L2 Building FE UNNES, Sekaran Campus, Gunungpati, Semarang
}

DOI 10.15294/aaj.v8i2.25629 unintentional errors from the client.

The phenomenon that occurs that is many cases of audit failure because auditor does not apply his scepticism in the practice of auditing. For example in the case of the freezing of the Public Accountant Meilina Pangaribuan license by the Minister of Finance of the Republic of Indonesia that the AP has accepted and carried out the audit engagement of PT Jui Shin Indonesia for fiscal year 2015 has been audited by another KAP. In this case, the AP has not fully complied with the professional code of ethics, and has not complied with the Audit Standards (SPAP) related to the absence of audit evidence in PT Jui Shin Indonesia's Financial Statements for the 2015 book year on sales accounts, cost of goods sales, and tax payable in conducting audits. The case of KAP audit failure Purwantono, Suherman \& Surja announced the results of the audit and provided a WTP opinion based on inadequate evidence of telecommunications companies in 2011. The finding began when Ernst \& Young's (EY) KAP partner in the US conducted a study of KAP audit results in Indonesia. They found that the audit results were not supported by appropriate data and evidence, namely in the leasing of more than 4 thousand cellular tower units. However, EY affiliated $\mathrm{KAP}$ released an audit result report with an unqualified status (WTP). 
Research conducted by Suraida (2005), Payne \& Ramsay (2005), Anisma et.al., (2011), and Oktania \& Suryono (2013) which state that experience has a significant effect on auditor professional scepticism. Different from research of Hadi (2014), the result obtained proves that the more experienced auditors the lower their professional scepticism. A'yun \& Kurnia (2015) and Handayani \& Ayu (2015) that auditor independence influences auditor professional scepticism, while research of Oktaviani (2015) shows that independence does not significantly influence on auditor professional scepticism. Charron \& Lowe (2008) found that female management was more sceptical than male. Whereas in the study of Larimbi (2012), the result indicates that gender has no effect on auditor professional skepticism.

This study aims to examine the effect of experience, independence, gender, and professional ethics variables on auditor professional scepticism. The originality of the research is to use the moderating variable of professional ethics which is also used as an independent variable. Ethics will lead auditors attitude and behaviour in carrying out audit tasks and basically the auditors carry out audit tasks in accordance with the ethical principles they hold, applicable regulations and audit procedures that have been prepared with due regard to objectivity, integrity, professional prudence and professional attitude. With this ethical impulse experience, independence, and gender can have a stronger effect on auditor professional scepticism.

Cognitive dissonance theory explains the effect of experience and independence on auditor professional scepticism with professional ethics as a moderator if there is a cognitive dissonance in the auditor when detecting fraud to remain sceptical. Gender influence on auditor professional scepticism is explained by the theory of selectivity hypothesis.

Experience is an important aspect of auditors in carrying out audit assignments. Nelson (2009) stated that the emerge of auditor professional scepticism can be facilitated from experience, when the experience has provided knowledge about the frequency of errors and non-errors, as well as showing misstatements in financial statements to high-risk evidence patterns. Sometimes the auditor will experience dissonance with complex tasks and the auditor's flying hours which are getting higher, causing high cognitive dissonance. The auditors will try to reduce the disharmony by changing their behaviour to be more professional. Research by Suraida (2005) and Payne \& Ramsay (2005) prove that experience influences auditor's professional scepticism. This is supported by research of Anisma et.al., (2011), and Oktania \& Suryono (2013) that experience significantly influences on auditor professional skepticism.

The auditor who has a lot of experience in auditing makes higher level of scepticism possessed by the auditor. Experienced auditors will be more selective about relevant information, thus influencing an auditor to have an attitude of professional scepticism.

\section{$\mathrm{H}_{1}$ : Experience partially has a significant positive effect on auditor professional scepticism}

Independent attitude is an attitude that is not easily influenced, by not having a conflict of interest, remains objective in every assessment and behaves by holding the principle of high integrity. Sukriah (2009) stated that support for independent attitude is needed when the auditor collects any information needed in making audit decisions. In the theory of cognitive dissonance which states that the gap between the two cognitive elements those are inconsistent and creates psychological discomfort. With the cognitive dissonance, someone will try to reduce the dissonance in order to be consistent. Auditors who have high trust to the client cause a high dissonance, so that they are satisfied with the client's explanation by not considering his professional prudence and not being vigilant. This causes the auditor's scepticism to be at a low level. Research of Attamimi (2015) shows that independence has a significant effect on auditor professional scepticism. The result of the study is supported by A'yun \& Kurnia (2015) and Handayani \& Ayu (2015) that auditor independence influences the auditor's professional scepticism. The higher the auditor's independent attitude, the higher the scepticism he has.

The more the auditor is independent in the audit, the higher the level of scepticism. Independent auditors will maintain their integrity, act objectively, and maintain an attitude of professional scepticism.

\section{$\mathrm{H}_{2}$ : Independence partially has a significant positive effect on auditor professional scepticism}

Male and female have differences in completing work and processing information which has more or less influenced the procedure of certain tasks in certain conditions. Bringing different values and traits between male and female to the workplace can cause different responses to their work. Differences in performance between male and female who have different characteristics make gender an indicator to measure auditor professional scepticism (Pratiwi \& Januarti, 2013). In the theory of selectivity hypothesis explains that there are fundamental differences between male and female in processing the information obtained. Female use all available information, be more comprehensive, and do an analysis of each available piece of information. Meanwhile, male are more likely to process information in a limited and not detailed manner. In this theory, it is assessed that female auditors are more sceptical than male auditors. Charron \& Lowe (2008) found that female management are more sceptical than male.

Gender is predicted to influence auditor professional scepticism, given that gender differences between male and female clearly influence the way they resolve problems, act and behave.

\section{$\mathrm{H}_{3}$ : Gender partially has a significant effect on audi- tor professional scepticism}

Professional ethics is a set of principles or moral values that are recognized and applied in professional accounting organizations. In cognitive dissonance theory, it is explained about the gap between two cognitive elements that are inconsistent and creating psychological discomfort. With the existence of cognitive dissonance, 
someone will try to reduce the dissonance in order to be consistent. The theory explains that auditor must always adhere to the professional code of ethics, so that when dissonance occurs that results in inconsistencies arising, the auditor can align the situation with his behaviour and attitudes in accordance with the auditor's professional ethics so that the auditor's professional scepticism is expected to be maintained.

Research by Suraida (2005), Gusti \& Ali (2008) and Silalahi (2013) find that ethics significantly influence auditor professional scepticism. This result is consistent with research by Winantyadi \& Waluyo (2014) and Attamimi (2015) that professional ethics significantly influence auditor professional scepticism.

\section{$\mathrm{H}_{4}$ : Professional Ethics partially has a significant positive effect on auditor professional scepti- cism}

In the basic principles of ethics, competence and professional prudence are stated that auditors in planning and carrying out audit assignments must be competent and professionally careful, assure clients that the auditors are competent in the field of auditing and having adequate expertise about audits and acting in earnest and be careful in accordance with applicable audit procedures and standards. With the existence of cognitive dissonance, someone will try to reduce the dissonance in order to be consistent. When dissonance occurs to auditors who have high flight hours and the complexity of the tasks handled by the auditors, they will try to be more professional in their assignments. The professionalism of an auditor indicates that the auditor complies with the professional code of ethics. Experience will have a stronger influence on auditor professional scepticism when the auditor has and adheres to professional ethics. Professional ethics will guide auditors to carry out assignments in accordance with their competencies and sufficient expertise regarding auditing and act seriously and carefully in accordance with applicable audit procedures and standards.

\section{$\mathrm{H}_{5}$ : Professional ethics strengthen the relationship between experience with auditor professional scepticism}

SPAP (2013) SA 220.A16 states that in an audit engagement concerning the public interest, as stipulated in the code of ethics, the auditor must be independent of the entity being audited. In cognitive dissonance theory, it is explained about the gap between two cognitive elements that are inconsistent and create psychological discomfort. With the existence of cognitive dissonance, someone will try to reduce the dissonance in order to be consistent. Pressure from the client can cause an auditor's independence to be in a weak spot so that the auditor is in a position of dilemma in his assignment. In this case, the auditor is required to fulfil the client's wishes but on the other hand, these actions can violate the professional standards set out in the code of ethics. Independence will increasingly have a stronger influence on auditor professional scepticism when the auditor has and holds fast to professional ethics. Professional et- hics will guide auditors to carry out assignments with an objective and independent attitude. In this case, ethics is predicted to strengthen the influence of independence with auditor professional scepticism.

\section{$\mathrm{H}_{6}$ : Professional ethics strengthen the relationship between independence and auditor professional scepticism}

One of the issues discussed in the ethics, business, and psychology literature is whether when identifying and acknowledging ethical or unethical events women are more sensitive than men, or whether women have a better background and moral development than men (Muthmainah, 2006). In the theory of cognitive dissonance which states that the gap between the two cognitive elements which are inconsistent and creates psychological discomfort. With the existence of cognitive dissonance, someone will try to reduce the dissonance in order to be consistent. Both male and female auditors must remain sceptical of the evidence and response from clients and remain vigilant as well as remain professional in accordance with the ethical principles of their profession. Professional ethics will guide auditors both male and female auditors to be sceptical in their audit work. Professional ethics binds all auditors regardless of gender, applies to both male and female auditors.

\section{$\mathrm{H}_{7}$ : Professional ethics strengthens the relationship between gender and auditor professional scepti- cism}

\section{RESEARCH METHODS}

This study used a quantitative approach. The population used was all Auditors or Public Accountants who work at KAP in Central Java and Yogyakarta Region registered in the IAPI directory in 2017 as many as 347 auditors. The sample is determined by convenience sampling technique, as many as 83 auditors. The variable used was the dependent variable that is auditor professional scepticism. Experience, independence, gender are as independent variables and professional ethics as an independent variable as well as a moderating variable. The definitions and measurements of variables are summarized in table 1.

The type of data was primary data with data collection technique using questionnaire technique. Data analysis techniques used descriptive statistics and moderated regression analysis (MRA). The MRA model is shown by equation 1 :

$$
\begin{aligned}
& Y=\alpha+\beta_{1} X_{1}+\beta_{2} X_{2}+\beta_{3} X_{3}+\beta_{4} Z+\beta_{5} X_{1}^{*} Z+\beta_{6} X_{2} * Z+ \\
& \boldsymbol{\beta}_{7} \mathbf{X}_{3} * \mathbf{Z}+\mathbf{e} \text {. }
\end{aligned}
$$

\section{RESULTS AND DISCUSSIONS}

Descriptive analysis of variables consists of the mean, maximum value, minimum value, and frequency distribution of each variable. The results of the descriptive analysis of the variables are presented in table 2 .

The Kolmogorov-Smirnov test shows the result that the data used in this study are normally distributed. 
Table 1. Research Variables and Measurement Indicators

\begin{tabular}{|c|c|c|}
\hline Variables & Definition & Indicators \\
\hline $\begin{array}{l}\text { Auditor } \\
\text { Professional } \\
\text { Scepticism (Y) }\end{array}$ & $\begin{array}{l}\text { Professional scepticism is an attitude that includes a } \\
\text { questioning mind, being alert to conditions which in- } \\
\text { dicate the possibility of misstatement caused by fraud } \\
\text { or error, and a critical assessment of audit evidence } \\
\text { (SPAP, } 2013 \text { section 200) }\end{array}$ & $\begin{array}{ll}\text { 1. } & \text { Questioning Mind } \\
\text { 2. Suspension of Judgment } \\
\text { 3. Search for Knowledge } \\
\text { 4. Interpersonal Understanding } \\
\text { 5. Self-confidence } \\
\text { 6. }\end{array}$ \\
\hline Experience $\left(\mathrm{X}_{1}\right)$ & $\begin{array}{l}\text { Is the level of mastery of auditor's knowledge and } \\
\text { skills in his work that can be measured by the length } \\
\text { of work, number of audits, and types of companies } \\
\text { that have been audited (Khoiriyah, 2013) }\end{array}$ & $\begin{array}{l}\text { 1. Length of work } \\
\text { 2. Number of audit tasks (Attamimi, } \\
\text { 2015) }\end{array}$ \\
\hline $\begin{array}{l}\text { Independence } \\
\left(\mathrm{X}_{2}\right)\end{array}$ & $\begin{array}{l}\text { independence as the attitude of a public accountant } \\
\text { to have no personal interest in carrying out his duties, } \\
\text { which is contrary to the principles of integrity and ob- } \\
\text { jectivity (Kode Etik IAI, 2011) }\end{array}$ & $\begin{array}{l}\text { 1. Independence in mind } \\
\text { 2. Independence in appearance } \\
\text { (Arens et.al., 2015) }\end{array}$ \\
\hline Gender $\left(\mathrm{X}_{3}\right)$ & $\begin{array}{l}\text { Gender is an analytical concept used to identify differ- } \\
\text { ences between men and women from a non-biological } \\
\text { perspective, namely from social, cultural, and psycho- } \\
\text { logical aspects (Muthmainah, 2006). }\end{array}$ & $\begin{array}{l}\text { 1. Female auditors rated } 0 \\
\text { 2. Male auditors rated } \\
\text { (Ghozali, 2016) }\end{array}$ \\
\hline $\begin{array}{l}\text { Professional } \\
\text { Ethics (Z) }\end{array}$ & $\begin{array}{l}\text { Professional ethics is a characteristic of a profession } \\
\text { that distinguishes one profession from another, which } \\
\text { functions to regulate the behaviour of its members } \\
\text { (Murtanto \& Marini 2003). }\end{array}$ & $\begin{array}{l}\text { 1. Personality } \\
\text { 2. Professional skills } \\
\text { 3. Responsibility } \\
\text { 4. mplementation of the code of } \\
\text { ethics } \\
\text { 5. Improvement of the code of ethics }\end{array}$ \\
\hline
\end{tabular}

Table 2. Descriptive test results of variables

\begin{tabular}{cccccccc}
\hline Interval & Frequency & $\%$ & Category & Min & Max & Mean & Category \\
\hline \multicolumn{2}{c}{ Auditor Professional Scepticism } & & & & & & \\
$52-60$ & 9 & $10.84 \%$ & Very sceptical & 31 & 59 & 45.76 & Sceptical \\
$42-51$ & 64 & $77.11 \%$ & Sceptical & & & & \\
$32-41$ & 9 & $10.84 \%$ & Neutral & & & & \\
$22-31$ & 1 & $1.21 \%$ & Not Sceptical & & & & \\
$12-21$ & 0 & $0 \%$ & Very Not Sceptical & & & & \\
Auditor Experience & & & & & & \\
$26-30$ & 38 & $45.78 \%$ & Very Experienced & 20 & 30 & 25.72 & Experienced \\
$21-25$ & 43 & $51.81 \%$ & Experienced & & & & \\
$16-20$ & 2 & $2.41 \%$ & Neutral & & & & \\
$11-15$ & 0 & $0 \%$ & Inexperienced & & & & \\
$6-10$ & 0 & $0 \%$ & Very Inexperienced & & & & \\
Auditor Independence & & & & & \\
$26-30$ & 41 & $49.40 \%$ & Very Independent & 18 & 30 & 25.77 & Independent \\
$21-25$ & 41 & $49.40 \%$ & Independent & & & & \\
$16-20$ & 1 & $1.20 \%$ & Neutral & & & & \\
$11-15$ & 0 & $0 \%$ & Not Independent & & & & \\
$6-10$ & 0 & $0 \%$ & Very Not Independent & & & & \\
Professional Ethics & & & & & \\
$57-65$ & 26 & $31.33 \%$ & Very ethical & 39 & 64 & 54.12 & Ethical \\
$46-56$ & 55 & $66.27 \%$ & Ethical & & & & \\
$35-45$ & 2 & $2.40 \%$ & Neutral & & & & \\
$24-34$ & 0 & $0 \%$ & Unethical & & & & \\
$13-23$ & 0 & $0 \%$ & Very Unethical & & &
\end{tabular}


It can be seen in Asymp. Sig. ( 2 tailed) value where the probability value is more than a significant level of 0.05 , that is the probability value which indicates the value of 0.343 . The multicollinearity test shows the result that the tolerance value of each independent variable shows value more than 0.10 and the VIF value does not exceed 10 , so there is no multicollinearity between the independent variables in the regression model. The heteroscedasticity test conducted with Glejser test shows the results of the probability of significance above 0.05 , which means that the research model has a homogeneous distribution and is free from heteroscedasticity. Based on the results of the MRA test, the regression equations that can be arranged in equation 2 :

$$
\begin{aligned}
Y= & -110.462+6.496 X_{1}-1.425 X_{2}+31.228 X_{3}+2.683 Z \\
& -0.109\left(X_{1} * Z\right)+0.023\left(X_{2} * Z\right)-0.549\left(X_{3} * Z\right) \ldots(2)
\end{aligned}
$$

The result of the regression analysis shows that the coefficient of determination of adjusted $\mathrm{R}$ square is 0.203 . This means that $20.3 \%$ of auditor professional scepticism can be explained by the variables of experience, independence, gender, and professional ethics. Meanwhile, the remaining 0.797 or $79.7 \%$ is explained by other variables outside the regression model. The results of partial hypothesis testing with a significance level of $\mathrm{a}=0.05$ are presented in Table 3 .

\section{The Effect of Experience on Auditor Professional Scepticism}

The result of the partial significance test indicates that the first hypothesis (H1) that is experience partially has a significant positive effect on auditor professional scepticism is accepted. Experience is an important aspect of auditors in conducting audit assignments. In the theory of cognitive dissonance, it is explained that basically, someone likes consistency and behaves in harmony. With the existence of cognitive dissonance, someone will try to reduce the dissonance in order to be consistent. Sometimes the auditor will experience dissonance with complex tasks and the auditor's flying hours which are getting higher, causing high cognitive dissonance. Auditors will try to reduce the disharmony by changing their behaviour to be more professional. The auditor's experience will bring the auditor to be more structured, proficient, and thorough in carrying out audit tasks.

Descriptive statistical test results in table 2 in the experience variable, the average auditor perceives that in the practice of auditing included in the experienced category. Furthermore, from the results of the descriptive analysis of the auditor's professional scepticism variable, the average auditor perceives that in the implementation of audit practices are included in the sceptical category. This means that the auditor professional scepticism in KAP in Central Java and Yogyakarta is one of them caused by the auditor's experience in implementing audit practices. The result of this study is in line with research by Suraida (2005), Payne \& Ramsay (2005), Anisma et.al., (2011), and Oktania \& Suryono (2013) which state that experience has a significant influence on auditor professional scepticism. The more experienced auditor, the higher the scepticism.

\section{The Effect of Independence on Auditor Professional Scepticism}

The result of the partial significance test shows that the second hypothesis (H2) of partially independence has a significant positive effect on auditor professional scepticism. Independent attitude is an attitude that is not easily influenced, by not having a conflict of interest, remains objective in every assessment and behaves by holding the principle of high integrity. The result of this study contradicts the cognitive dissonance theory, when dissonance occurs, the auditors in their assignment is required to take an attitude that is contrary to their personal attitudes, thus making auditors tend to change their attitudes to be aligned with what should be done. In this study, the attitude of independence that should be applied by the auditor has not been fully applied by the auditor so that independence becomes weak and results in weak auditor professional scepticism.

Descriptive statistical test results in table 2 in the auditor independence variable, the average auditor perceives that in the implementation of audit practices included in the independent category. Furthermore, from

Table 3. Summary of Hypothesis Testing

\begin{tabular}{clccc}
\hline \multicolumn{1}{c}{ Hypothesis } & $\beta$ & Sig. & Results \\
\hline $\mathrm{H}_{1}$ & $\begin{array}{l}\text { Experience partially has a significant positive effect on auditor pro- } \\
\text { fessional scepticism }\end{array}$ & 6.496 & 0.049 & Accepted \\
$\mathrm{H}_{2} \quad \begin{array}{l}\text { Independence partially has a significant positive effect on auditor } \\
\text { professional scepticism }\end{array}$ & -1.425 & 0.663 & Rejected \\
$\mathrm{H}_{3} \quad \begin{array}{l}\text { Gender partially has a significant positive effect on auditor profes- } \\
\text { sional scepticism }\end{array}$ & 31.228 & 0.018 & Accepted \\
$\mathrm{H}_{4} \quad \begin{array}{l}\text { Professional ethics partially have a significant positive effect on au- } \\
\text { ditor professional scepticism }\end{array}$ & 2.683 & 0.021 & Accepted \\
$\mathrm{H}_{5} \quad \begin{array}{l}\text { Professional ethics strengthen the relationship between experience } \\
\text { with auditor professional scepticism }\end{array}$ & -0.109 & 0.061 & Rejected \\
$\mathrm{H}_{6} \quad \begin{array}{l}\text { Professional ethics strengthen the relationship between indepen- } \\
\text { dence and auditor scepticism }\end{array}$ & 0.023 & 0.692 & Rejected \\
$\mathrm{H}_{7} \quad \begin{array}{l}\text { Professional ethics strengthens the relationship between gender } \\
\text { and auditor professional scepticism }\end{array}$ & -0.549 & 0.023 & Rejected \\
\hline
\end{tabular}


the results of the descriptive analysis of the auditor's professional scepticism variable, the average auditor perceives that in the implementation of audit practices are included in the sceptical category. Most of the respondents in this study are junior auditors. In every preparation of the audit, every decision involves the team leader and members of the audit team, so that intervention is possible that causes the junior auditor to become not independent. In addition to these external factors, it can also be from the internal factors of auditor behaviour that require the auditor to be not independent.

An independent auditor will be more free in giving his opinion, with high independence, the auditor is able to reveal the mistakes made by the client, so the auditor gives his opinion appropriately (Zu'amah, 2009). This happens because auditors often become not independent due to external factors that demand that an auditor is not independent.

\section{The Effect of Gender on Auditor Professional Scepti- cism}

The results of the partial significance test show that the third hypothesis (H3), gender partially has a significant positive effect on auditor professional scepticism is accepted. Differences in performance between female and male have different characteristics to make gender an indicator to measure auditor professional scepticism. Descriptive statistical test results in this study indicate that male auditors are more sceptical than female auditors. In the workplace, male and female carry different values and traits which cause different responses to their work. Male auditors are more sceptical because social and cultural conditions, values and behaviuor, mentality, and emotionality which are better than female auditors. In the theory of cognitive dissonance, it is explained that basically, someone likes consistency and behaves in harmony. With the existence of cognitive dissonance, someone will try to reduce the dissonance in order to be consistent, both male auditors and female auditors must remain sceptical of the evidence and the response from the client and remain vigilant as well as remain professional in accordance with the ethical principles of his profession. Therefore, gender influences on auditor's professional scepticism.

The result of this study is different from the research of Larimbi (2012) that gender does not affect on auditor professional scepticism. The result of this study is supported by the study of Charron \& Lowe (2008) that gender affects on auditor's professional scepticism.

\section{The Effect of Professional Ethics on Auditor Profes- sional Scepticism}

The result of the partial significance test shows that the fourth hypothesis (H4) which states that professional ethics partially has a significant positive effect on auditor's professional scepticism is accepted. The results of descriptive statistical test in table 2 in the professional ethics variable, the average auditor perceives that in carrying out audit practices included in the ethical category. Furthermore, from the results of the descriptive analysis of the auditor's professional scepticism variable, the average auditor perceives that in the implementation of his audit practices is included in the sceptical category. This means that the auditor's professional scepticism in KAP in Central Java and Yogyakarta is one of them caused by the ethical awareness of an auditor to remain guided by and maintain a code of ethics in the implementation of audit practices.

The auditor's obligation to maintain ethical behaviour and adhere to a code of ethics as an accountant influences his professional scepticism. The auditor who obeys the code of ethics, the more the auditor is ethical the more his professional scepticism will be. Referring to the theory of cognitive dissonance states that basically someone likes consistency and behaves in harmony, with the existence of cognitive dissonance, someone will try to reduce the dissonance in order to be consistent. This means, humans are often required to do behaviour that is contrary to his attitude. Auditors or a public accountant who has high ethical awareness means having a commitment to apply the public accountant's code of ethics. This commitment will prevent the auditor from committing violations that are contrary to professional ethics. Professional ethics lead auditors to act and behave as they should. Auditors who are ethical or apply ethics will be sceptical, to achieve qualified audits.

The result of this study is supported by research of Suraida (2005), Gusti \& Ali (2008), Silalahi (2013), Winantyadi \& Waluyo (2014) and Attamimi (2015) that ethics has a significant effect on auditor professional scepticism. The more ethical an auditor will be, the higher the level of professional scepticism owned by the auditor.

\section{The Interaction of Professional Ethics and Experi- ence with Auditor Professional Scepticism}

The results of the partial significance test show that the fifth hypothesis (H5) of professional ethics strengthens the relationship between experience and auditor professional scepticism is rejected. It is basically someone likes consistency and behaves in harmony. With the existence of cognitive dissonance, someone will try to reduce the dissonance in order to be consistent. When dissonance occurs with complex auditor tasks and auditor flight hours that are increasingly high, it causes high cognitive dissonance. The auditors will try to reduce the disharmony by changing their behaviour to be more professional. However, in this study, high ethical awareness and sufficient auditor experience may not necessarily make an auditor more sceptical.

In this study, the interaction of professional ethics and experience has no effect on auditor professional scepticism. The auditor's scepticism can be influenced by external factors from the auditor, not from the internal factors of the experience and ethical awareness of an auditor. The external factor, for example, is the longstanding relationship with the client, which makes the auditor not sceptical in his audit assignments. Adequate auditor experience and maintained professional ethics from an auditor do not make an auditor to be sceptical. 
Interaction of Professional Ethics and Independence on Auditor Professional Scepticism

The results of the partial significance test show that the sixth hypothesis (H6) of professional ethics reinforces the relationship between independence and auditor professional scepticism is rejected. The result of this study contradicts the cognitive disssonance theory, which states that basically someone likes consistency and behaves in harmony. With the existence of cognitive dissonance, someone will try to reduce the dissonance in order to be consistent. When dissonance occurs, then the auditor in his assignment is required to take an attitude that is contrary to their personal attitude, thus making auditors tend to change their attitudes to be in line with what should be done. In this study, the attitude of independence and professional ethics that should be applied by the auditor has not been fully applied by the auditor so that independence becomes weak and ethical awareness decreases resulting in weak auditor professional scepticism.

The interaction of professional ethics and independence in this study do not influence auditor professional scepticism. The auditor's scepticism can be influenced by external factors from the auditor, not from the internal factors of independence and ethical awareness of an auditor. The external factor is the pressure obtained from the client which can cause the independence of an auditor to be in a weak spot so that the auditor is in a position of dilemma in his assignment. In this case, the auditor is required to fulfil the client's wishes but on the other hand, this action can violate the professional standards set out in the code of ethics. Auditor independence and professional ethics maintained by an auditor do not make an auditor be sceptical.

\section{Interaction of Professional Ethics and Gender with Auditor Professional Scepticism}

The results of the partial significance test show that the seventh hypothesis (H7), professional ethics strengthen the relationship between gender and auditor professional scepticism is rejected. Professional ethics will guide auditors both male and female auditors to be sceptical in carrying out their audit duties. In the theory of cognitive dissonance explained that basically someone likes consistency and behaves in harmony. With the existence of cognitive dissonance, someone will try to reduce the dissonance in order to be consistent, both male and female auditors must remain sceptical on the evidence and response from the client and remain vigilant and professional in accordance with the ethical principles of his/her profession.

The interaction of professional ethics and gender in this study do not affect auditor professional scepticism. Auditors' scepticism can be influenced by external factors of auditors, not from internal factors, gender, and ethical awareness from an auditor. Internal factors of social and cultural conditions, values and behaviour, mentality, and good emotion of an auditor will make the auditor understand and have high ethical awareness. Auditors' adherence to professional ethics does not make male or female auditors more sceptical in carrying out their assignments. The professional ethics of auditors actually weakens the sceptical attitude of male and female auditors becoming weaker. This is because the auditors understand the location of the gap of professional ethics so that male and female auditors can put aside their scepticism, so their professional scepticism becomes weak in their audit practices.

\section{CONCLUSIONS}

The results of this study indicate that auditor experience, gender, and professional ethics have significant positive effects on auditor professional scepticism, while independence, interaction of experience and professional ethics, interaction of independence and professional ethics as well as interaction of gender and auditor professional ethics do not significantly influence on auditor professional scepticism. The simultaneous test shows a significant effect between the variables of experience, independence, gender, professional ethics, the interaction of experience and professional ethics, the interaction of independence and professional ethics as well as the interaction of gender and professional ethics on professional scepticism. Further research is suggested to use other factors that can influence auditor professional scepticism such as workload and audit fees. Workload and audit fees are theoretically capable of influencing auditor professional scepticism. The amount of workload owned by the auditor will cause the auditor to abandon his scepticism and related audit fees given by the client, high audit fees will pressure the auditor to give an opinion in accordance with the client's request.

\section{REFERENCES}

A'yun, Q., \& Kurnia. (2015). Faktor-Faktor yang Mempengaruhi Skeptisme Profesional Auditor pada Kantor Akuntan Publik. Jurnal Ilmu \& Riset Akuntansi, 6(7), 1-24.

Anisma, Y., Abidin, Z., \& Cristina. (2011). Faktor yang Mempengaruhi Sikap Skeptisme Profesional Seorang Auditor pada Kantor Akuntan Publik di Sumatera. Pekbis jurnal, 3(2), 490-497.

Arens, A. A., Randal J. E. \& Mark S. B. (2014). Auditing dan Jasa Assurance, Edisi Kelimabelas. Terjemahan Gina Gania dan Tim Perti. Jakarta: Penerbit Erlangga.

Attamimi, F. M. (2015). Faktor-faktor yang mempengaruhi Skeptisisme Profesional Auditor. Jurnal Ilmu \& Riset Akuntansi, 4(7), 1-22.

Charron, K.F., \& Lowe, J. (2008). Skepticism and the Management Accountant: Insights for Fraud Detection. Management Accounting Quarterly Winter, 9(2), 9-15.

Gusti, M \& Ali, S. (2008). Hubungan Skeptisisme Profesional Auditor dan Situasi Audit, Etika, Pengalaman serta Keahlian Audit dengan Ketepatan Pemberian Opini Auditor oleh Akuntan Publik. In Simposium Nasional Akuntansi 8 Padang.

Ghozali, I. (2016). Aplikasi Analisis Multivariate dengan Program IBM SPSS 23. Semarang: Badan Penerbit Universitas Diponegoro.

Handayani, K. A. T., \& Merkusiwati, L. A. (2015). Pengaruh Independensi Auditor dan Kompetensi Auditor pada Skeptisisme Profesional Auditor dan Implikasinya terhadap Kualitas Audit. E-Jurnal Akuntansi Universitas 
Udayana, 10(1), 229-243.

Hadi, S. (2014). Pengaruh Independence in Attitude dan Pengalaman terhadap Skeptisisme Profesional Auditor. EKBISI, VIII(2), 218-234.

Ikatan Akuntan Indonesia. 2013. Standar Profesional Akuntan Publik. Jakarta: Salemba Empat.

Ikatan Akuntan Indonesia. 2016. Exposure Draft Kode Etik Akuntan Profesional.

Khoiriyah, S. L. 2013. Analisis Faktor Personal dan Pertimbangan Etis terhadap Perilaku Auditor pada Situasi Konflik Audit. Accounting Analysus Journal, 2 (4), 369-377.

Kushasyandita, R. S., \& Januarti, I. (2012). Pengaruh Pengalaman, Keahlian, Situasi Audit, Etika dan Gender terhadap Ketepatan Pemberian Opini Auditor melalui Skeptisisme Profesional Auditor (Studi Kasus Pada KAP Big Four di Jakarta). Sistem Informasi, Etika Dan Auditing, 1-34.

Larimbi, D. (2012). Pengaruh Faktor-Faktor Personal terhadap Skeptisisme Profesional Auditor. Ekuitas: Jurnal Ekonomi dan Keuangan, (80), 89-107.

Murtanto \& Marini. (2003). Persepsi Akuntan Pria dan Wanita serta Mahasiswa dan Mahasiswi terhadap Etika Bisnis dan Etika Profesi. Proceding Simposium Nasional Akuntansi (SNA) VI.

Muthmainah, S. (2006). Studi tentang Perbedaan Evaluasi Etis, Intensi Etis (Ethical Intention) dan Orientasi Etis Dilihat dari Gender dan Disiplin Ilmu: Potensi Rekruitmen Staf Profesional pada Kantor Akuntan Publik. In Simposium Nasional Akuntansi (SNA) 9 Padang.

Nelson, M. W. (2009). A Model and Literature Review of Professional Skepticism in Auditing. Auditing: A Journal of Practice \& Theory, 28 (2), 1-34
Oktania, R., \& Suryono, B. (2013). Faktor-faktor yang berpengaruh terhadap Skeptisisme Profesional Auditor. Jurnal Ilmu \& Riset Akuntans, 2(12), 1-21.

Payne, E. A., \& Ramsay, R. J. (2005). Fraud risk assessments and auditors' professional skepticism. Managerial Auditing Journal, 20(3), 321-330.

Prasetya, I. W. A., \& Sari, M. M. R. (2014). Independensi, Profesionalisme, dan Skeptisme Profesional Auditor sebagai Prediktor Ketepatan Pemberian Opini Auditor. E-Jurnal Akuntansi Universitas Udayana, 9(2), 273-284.

Pratiwi, A. B., \& Januarti, I. (2013). Pengaruh Faktor-Faktor Skeptisisme Profesional Auditor Terhadap Pemberian Opini (Studi Empiris Pada Pemeriksa Bpk Ri Provinsi Jawa Tengah ). Diponegoro Journal of Accounting, 2(1), $1-14$.

Silalahi, S. P. (2013). Pengaruh Etika, Kompetensi, Pengalaman Audit dan Situasi Audit terhadap Skeptisme Profesional Auditor. Jurnial Ekonomi, 21 (3), 1-21.

Sukriah, I., Akram,,\&Inapty, B. A. 2009. Pengaruh Pengalaman Kerja, Independensi, Objektivitas, Integritas, dan Kompetensi terhadap Kualitas Hasil Audit. Simposium Nasional Akuntansi XII. Palembang.

Suraida, I. (2005). Pengaruh Etika, Kompetensi, Pengalaman Audit dan Risiko Audit terhadap Skeptisisme Profesional Auditor dan Ketepatan Pemberian Opini Akuntan Publik. Sosiohumaniora, 7(3), 186-202.

Winantyadi, N., \& Waluyo, I. (2014). Pengaruh Pengalaman, Keahlian, Situasi Audit, Etika terhadap Skeptisisme Profesional Auditor. Jurnal Akuntansi Dan Keuangan, $3(1), 1-21$.

Zu'amah, S. (2009). Independensi dan Kompetensi Auditor pada Opini Audit Studi Bpkp Jateng. Jurnal Dinamika Akuntansi, 1(2), 145-154. 